Volume 11, Nomor 1, Januari 2020

\title{
Peran Brand Image dalam Memediasi Pengaruh Social Media Marketing terhadap Repeat Purchase pada Fast-Food Restaurant di Kota Medan
}

\section{The Role of Brand Image in Mediating the Effects of Social Media Marketing toward Repeat Purchase at Fast-Food Restaurant in Medan City}

\author{
Muhammad Fahmi ${ }^{1)}$, Muhammad Arif ${ }^{2)}$, Salman Farisi ${ }^{3)}$, Nadia Ika Purnama ${ }^{4)}$ \\ ${ }^{1,2,3,4)}$ Fakultas Ekonomi dan Bisnis, Universitas Muhammadiyah Sumatera Utara, Medan \\ e-mail korespondensi: muhammadfahmi@umsu.ac.id
}

\begin{tabular}{|l|}
\hline Info Artikel \\
\hline Riwayat Artikel : \\
Diterima: 29 Oktober 2019 \\
Disetujui: 26 November 2019 \\
Dipublikasikan: Januari 2020
\end{tabular}

Nomor DOI

10.33059/jseb.v11i1.1722

Cara Mensitasi :

Fahmi, M., Arif, M., Farisi, S. \& Purnama, N.I. 2020. Peran

Brand Image dalam Memediasi Pengaruh Social Media

Marketing terhadap Repeat

Purchase pada Fast-Food

Restaurant di Kota Medan. Jurnal Samudra Ekonomi dan Bisnis. 11(1): 53-68.

\begin{abstract}
Abstrak
Penelitian ini bertujuan untuk menganalisis pengaruh social media marketing pada brand image dan repeat purchase, dan untuk menganalisis peran brand image dalam memediasi pengaruh social media marketing terhadap repeat purchase di industri Fast-Food Restaurant di Kota Medan. Responden adalah konsumen yang melakukan pembelian di lima restoran cepat saji di Medan. 140 orang dipilih menggunakan random sampling. Data dikumpulkan menggunakan kuesioner dan wawancara, dan dianalisis menggunakan analisis deskriptif dan analisis jalur. Hasilnya membuktikan bahwa social media marketing secara signifikan mempengaruhi brand image; brand image secara signifikan mempengaruhi repeat purchase; dan, social media marketing secara signifikan mempengaruhi repeat purchase. Selain itu, social media marketing terbukti tidak berpengaruh signifikan terhadap repeat purchase melalui brand image sebagai mediator.
\end{abstract}

Kata Kunci: Social Media Marketing, Brand Image, Repeat Purchase.

\begin{tabular}{|l|}
\hline Article Info \\
\hline Article History: \\
Received: 29 October 2019 \\
Accepted: 26 November 2019 \\
Published: January 2020 \\
\hline DOI Number : \\
10.33059/jseb.v11i1.1722 \\
How to cite: \\
Fahmi, M., Arif, M., Farisi, S. \\
\& Purnama, N.I. 2020. Peran \\
Brand Image dalam Memediasi \\
Pengaruh Social Media \\
Marketing terhadap Repeat \\
Purchase pada Fast-Food \\
Restaurant di Kota Medan. \\
Jurnal Samudra Ekonomi \\
dan Bisnis. 11(1): 53-68.
\end{tabular}

\section{Abstract}

This study aims to analyze the effect of social media marketing on brand image and repeat purchases, and to analyze the role of brand image in mediating the effect of social media marketing on repeat purchases in the Fast-Food Restaurant industry in Medan. The respondents are consumers who have made purchases at five fast food restaurants in Medan. 140 people were selected using random sampling. Data collected using questionnaire and interviews, and analyzed using descriptive and path analysis. The results proved that social media marketing was significantly influenced brand image; brand image was significantly influenced repeat purchase; and, social media marketing was significantly influenced repeat purchase. Moreover, social media marketing proved has no significant effect on repeat purchase through brand image as mediator.

Keywords: Social Media Marketing, Brand Image, Repeat Purchase. 


\section{PENDAHULUAN}

Era globalisasi menyebabkan kondisi perusahaan harus dapat bergerak secara dinamis. Keadaan atau kondisi yang dinamis menuntut perkembangan industri atau perusahaan atau organisasi untuk bergerak dengan cepat dalam menyesuaikan keadaan. Proses modernisasi juga mempengaruhi setiap aspek kehidupan ekonomi, sosial budaya, penyediaan pangan, teknologi pangan, dan teknologi komunikasi dan informasi. Salah satunya adalah industri cepat saji atau yang disebut fast-food restaurant yang merupakan industri yang sudah tidak asing lagi di Indonesia (Kristiani \& Dharmayanti, 2017).

Keunggulan kompetitif dalam industri makanan saat ini merupakan hal yang perlu diperhatikan. Tantangan di dalam dunia pemasaran dalam upaya mempertahankan keberadaan dan sustainabilitas perusahaan merupakan yang paling penting untuk dibahas. Oleh karena itu, pemasar melihat peluang melalui digital marketing merupakan salah satu alat yang dapat digunakan dalam menjangkau konsumen. Melalui media sosial yang merupakan salah satu alat yang paling efektif dalam menjangkau konsumen. Selain itu, fakta yang mendukung sosial media merupakan salah satu alat yang paling strategis dalam menjangkau konsumen adalah sekitar 89 persen masyarakat Indonesia menggunakan internet hanya untuk dipakai mengakses sosial media. Media sosial yang digunakan di dalam penelitian ini adalah menggunakan facebook dan twitter karena dapat membangun friendly attention dan stimulasi konsumen terhadap merek tersebut (Kim \& Ko, 2010).

Saat ini, media sosial dinilai cukup berkembang di Indonesia dan memiliki peluang untuk dijadikan sebagai tempat pemasaran bagi para pelaku bisnis yang ingin memasarkan produk/jasanya. Media sosial merupakan bagian terpenting dari strategi penjualan, pelayanan, komunikasi, maupun pemasaran yang lebih besar dan lebih lengkap serta merefleksikan dan menyesuaikan diri dengan pasar dan orang-orang yang mengartikannya (Solis, 2011). Media sosial adalah pemasaran yang paling berpengaruh alat yang telah berevolusi dalam waktu yang lebih singkat periode dan memiliki ribuan koneksi yang terpapar ke dalam kegiatan pemasaran tanpa memandang waktu, batas atau wilayah (Lipsman et al., 2012).

Saat ini, pemasaran berubah lebih cepat dari sebelumnya. Komunikasi baru setiap hari berarti muncul. Baru-baru ini, media telah dikategorikan menjadi pendekatan tradisional dan non-tradisional. TV dan surat kabar adalah contoh media tradisional. Pelanggan sekarang menggunakan media sosial untuk terhubung, mencari, dan bertukar informasi, pemikiran, dan pengalaman merek dan perusahaan. Facebook, Instagram, MySpace, YouTube, dan Twitter digunakan untuk berbagi pengalaman baik atau negatif (Mihalcea \& Savulescu, 2013). Media sosial memiliki beberapa macam channel yang beragam diantaranya adalah blogs, social networking services, social media sharing services, social bookmarking services, social news services, social geolocation and meeting services, dan community building services (Zimmerman \& Sahlin, 2011).

Seperti yang dikemukakan oleh Li dan Bernoff (2011), platform media sosial menawarkan kesempatan bagi pelanggan untuk berinteraksi dengan konsumen lain. Dengan demikian, perusahaan tidak lagi menjadi satu-satunya sumber komunikasi merek. Selain itu, konsumen semakin menggunakan situs media sosial untuk mencari informasi dan berpaling dari media tradisional, seperti televisi, radio, dan majalah (Mangold \& Faulds, 2009). Fenomena ini telah mengurangi kontrol pemasar terhadap manajemen merek (Berthon et al., 2007). 
Profil dan informasi produk dan perusahaan di jaringan media sosial adalah diasumsikan sebagai sumber yang andal dan kredibel, lebih dapat diandalkan dan layak daripada tipe pemasaran tradisional (Bruhn et al., 2012).

Menurut para peneliti dalam pemasaran tradisional, konsumen akan memberi tahu tujuh hingga sepuluh orang tentang produk tersebut, tetapi sekarang bersifat media sosial memungkinkan konsumen untuk berbagi pengalaman dengan pelanggan lain dalam waktu singkat (Mangold \& Faulds, 2009). Media sosial memainkan peran penting dalam membangun merek juga. Ekuitas merek berbasis konsumen adalah evaluasi intangible dari merek dan subyektif untuk konsumen, sebagai hasilnya nilai yang dirasakan secara objektif. Empat dimensi utama ekuitas merek adalah kesadaran dan asosiasi merek pelanggan, pelanggan loyalitas merek dan persepsi kualitas merek (Heidemann et al., 2012).

Oleh karena itu, sangat penting untuk memahami persepsi pelanggan terhadap merek tidak lagi hanya dipengaruhi oleh apa yang dikomunikasikan oleh perusahaan, tetapi apa yang pelanggan katakan tentang merek tertentu juga. Penyebaran viral informasi di antara orang-orang melalui media sosial jauh lebih kuat daripada media tradisional seperti TV, radio, dan iklan cetak (Keller, 2009). Persepsi kepada sebuah brand pada industri fast-food restaurant merupakan hal yang penting dalam terjadinya repeat purchase. Tentunya, repeat purchase ini merupakan hal yang sangat penting dalam dijadikan patokan untuk mempertahankan keberadaan dan sustainability industri fast-food restaurant.

Selain itu, brand image juga merupakan persepsi tentang brand yang tercermin dari asosiasi merek yang tertanam di dalam memori konsumen (Keller, 2009). Brand image sangat penting bagi keberhasilan produk, karena pada saat pembelian suatu produk, orang akan cenderung membeli mereknya. Merek adalah nama, tanda, simbol, atau kombinasinya, yang ditunjukkan untuk mengidentifikasi (membedakan) barang atau layanan suatu penjual dari barang dan layanan penjual lainnya (Simamora, 2000).

Beberapa hasil penelitian terdahulu menunjukkan terdapat beberapa faktor yang berpengaruh terhadap repeat purchase. Hasil-hasil penelitian As'ad dan Alhadid (2014) serta Kristiani dan Dharmayanti (2017) menunjukkan bahwa social media marketing memiliki pengaruh terhadap brand image. Hasil penelitian Pamungkas dan Widodo (2018) menunjukkan Brand image berpengaruh terhadap keputusan pembelian ulang yang dimediasi oleh level kepuasan konsumen. Begitu juga hasil-hasil penelitian milik Damayanti dan Wahyono (2015) serta Kristiani dan Dharmayanti (2017) yang menunjukkan bahwa terdapat pengaruh brand image terhadap repeat purchase. Selanjutnya hasil penelitian Kristiani dan Dharmayanti (2017) menunjukkan bahwa social media marketing berpengaruh terhadap repeat purchase. Penelitian milik Kuspriyono dan Nurelasari (2018) menunjukkan bahwa social media marketing memiliki pengaruh positif dan signifikan terhadap purchase intention.

Beberapa perbedaan hasil yang terdapat dalam penelitian-penelitian tersebut memiliki adanya research gap, sehingga dinilai perlu dilakukan kajian penelitian tentang hubungan antara faktor-faktor tersebut dengan repeat purchase. Berdasarkan dasar pemikiran itu, maka rumusan masalah dalam penelitian ini yaitu: (1) apakah social media marketing berpengaruh terhadap brand image dan repeat purchase?; (2) apakah brand image berpengaruh terhadap repeat purchase?; serta, (3) apakah brand image berperan dalam memediasi pengaruh social media marketing terhadap repeat purchase? 


\section{Repeat Purchase}

Dalam pemasaran banyak peneliti telah menyoroti pentingnya pembelian berulang (repeat purchase). Semua penjual tertarik dalam mengetahui bagaimana konsumen membuat keputusan pembelian mereka dan apa yang memotivasi mereka untuk membeli kembali. Pembelian ulang adalah sumber utama bagi terciptanya pendapatan dan pembangunan hubungan jangka panjang untuk bisnis ritel (Gupta \& Kim, 2007). Hal ini tidak hanya membawa pendapatan bagi perusahaan, tapi juga menggambarkan adanya hubungan positif dari sisi konsumen yang kemudian dapat menghasilkan positif word of mouth dan pelanggan setia bagi perusahaan.

Transaksi online perusahaan juga harus mampu mengikat pelanggan kedalam bentuk hubungan yang kuat (Chairunnisa \& Priyono, 2018). Hal ini bertujuan agar pelanggan melakukan pembelian berulang. Pembelian kembali telah didefinisikan oleh Chou dan Hsu (2015) sebagai penggunaan kembali saluran online pelanggan untuk membeli dari pengecer tertentu. Niat pembelian digambarkan sebagai pola perilaku transaksi yang ditunjukkan pelanggan setelahnya membuat evaluasi barang dan jasa (Schiffman \& Kanuk, 2010).

Telah dikonfirmasi berkali-kali bahwa pelanggan yang berulang membawa lebih banyak keuntungan ke perusahaan, karena pelanggan yang berpengalaman lebih murah untuk mempertahankan, dan karena mereka sudah akrab dengan pembelian online proses, mereka menghabiskan lebih sedikit waktu dalam mengevaluasi dan melakukan transaksi pembelian (Chiu et al., 2014). Menurut Ndubisi dan Moi (2005), pembelian ulang (repeat purchase) tergantung pada tingkat ketahanan suatu produk. Niat pembelian berulang terjadi ketika konsumen memulai upaya untuk membeli merek, produk, atau layanan yang sama lagi. Ini berfungsi sebagai pendahulu ataupun prediktor untuk aktual perilaku pembelian (Lin \& Liang, 2011; Kuo et al., 2013; Aisha \& Kurnia, 2018).

\section{Brand Image}

Brand atau merek merupakan suatu yang penting di dalam meningkatkan minat beli di dalam masyarakat. Brand juga adalah sesuatu aspek yang perlu dipertimbangkan. Beberapa praktisi dan peneliti juga setuju mengenai pentingnya menekankan brand image (Aaker, 2008). Iversen dan Hem (2008) menyatakan bahwa brand image mewakili simbolisme pribadi konsumen yang terdiri dari semua definisi dan evaluasi yang terkait dengan merek.

Brand image adalah persepsi tentang merek atau brand yang tercermin dari asosiasi merek yang tertanam di dalam memori konsumen (Keller, 2009). Brand image merupakan sekelompok keyakinan konsumen yang berpegang pada merek tertentu (Kotler, 2005). Brand image dibentuk dari bermacammacam asosiasi brand yang konsumen kembangkan dalam pikiran mereka (Jokinen, 2016).

Brand image dapat juga didefinisikan sebagai persepsi yang terkandung dalam memori konsumen tentang suatu merek itu tercermin dari asosiasi merek (Lee et al., 2011). Brand image berisi informasi dan ideide yang dimiliki konsumen tentang berbagai produk merek dan fitur produk (Lee et al., 2011). Citra mental yang dimiliki konsumen tentang suatu merek telah terbentuk sebagai hasil dari komunikasi pemasaran, pengalaman konsumsi, dan efek sosial (Riezebos, 2003). Efek dari faktor-faktor ini pada pikiran konsumen mempengaruhi sikap konsumen terhadap merek dan kepercayaan (Yang et al., 2011).

Brand image menurut Kotler dan Keller (2009) adalah persepsi dan keyakinan yang dipegang konsumen, seperti dicerminkan oleh 
asosiasi yang tertanam di dalam ingatan konsumen, yang selalu diingat pertama kali saat mendengar slogan. Pemberian brand image atas suatu produk dipengaruhi oleh beberapa faktor yang menurut Kotler (2005) yaitu atribut, manfaat, nilai-nilai, budaya, kepribadian dan pemakaian.

\section{Social Media Marketing}

Social Media adalah lingkungan online tempat orang-orang dengan minat yang samasama mendukung untuk berbagi, komentar, dan mendukung mereka (Weber, 2007). Penggunaan platform komunikasi online berdasarkan penggunaan Internet dan teknologi berbasis seluler dalam aksi pemasaran oleh bisnis sangat penting berupa efek yang diperuntukkan konsumen terhadap produk dan merek mereka dan disajikan yang mereka buat pada konsumen lain (Sigala \& Marinidis, 2009; Chen et al., 2011).

Social Media atau media sosial adalah istilah untuk menggambarkan jenis media yang didasarkan pada percakapan online dan interaksi antar manusia. Media sosial juga muncul dalam berbagai bentuk, termasuk forum Internet, blog sosial, microblogging, gambar, dan video. Juga mencakup teknologi seperti email, berbagi gambar, blog, posting di dinding, dan berbagi musik (Strauss \& Frost, 2009). Media sosial itu memiliki lima karakteristik, yaitu: Partisipasi, Keterbukaan, Percakapan, Komunitas, dan Keterhubungan (Mayfield, 2008).

\section{Social Media Marketing (SMM)} melibatkan metode yang berkaitan dengan pemasaran langsung dan tidak langsung untuk menghasilkan kesadaran konsumen, pengakuan dan penarikan kembali untuk suatu produk, orang atau merek yang dieksekusi melalui alat web jejaring sosial, penyebaran konten dan microblogging (Gunelius, 2011). Dalam istilah yang lebih sederhana, ini disebut sebagai praktik periklanan yang dilakukan secara online, yang memanfaatkan karakteristik etnis suatu masyarakat, dalam bentuk jejaring sosial (Facebook serta YouTube), jejaring virtual (Second Life) dan situs yang berorientasi pada pendapat (Eopinions) demi mencapai tujuan pemasaran strategis (Tuten, 2008).

SMM dapat didefinisikan sebagai penggunaan platform Social Media yang ada untuk meningkatkan kesadaran merek di antara konsumen di platform online melalui pemanfaatan prinsip-prinsip WOM (Drury, 2008). Dengan demikian, hal ini mendukung dua bentuk promosi. Bentuk pertama adalah promosi pemasaran tradisional, yang mengacu pada komunikasi yang didorong oleh perusahaan terhadap pelanggan mereka. Bentuk kedua adalah promosi sosial, yang unik untuk platform Social Media dan diwujudkan dalam konsumen - komunikasi kepada konsumen (Mangold \& Faulds, 2009). Social Media Marketing terkait dengan pemasaran hubungan, dimana perusahaan perlu bergeser dari "mencoba menjual" ke "membuat koneksi" dengan konsumen (Gordhamer, 2009). Perusahaan juga perlu menjauh dari kampanye besar dan tetap dengan tindakan kecil karena beberapa kampanye kecil dapat dengan mudah menjangkau banyak orang dan mencapai tujuan dalam periode waktu yang sangat singkat (Coon, 2010).

Menurut Gunelius (2011), terdapat empat elemen yang dijadikan sebagai variabel kesuksesan social media marketing, yaitu: (1) Content Creation; (2) Content Sharing; (3) Connecting; dan, (4) Community Building. Berdasarkan hasil penelitian terdahulu milik Shojaee dan Azman (2013), terdapat tiga variabel dalam Social Media Marketing, yaitu: (1) Brand Exposure; (2) Customer Engagement; dan, (3) Electronic Word of Mouth. 


\section{Kerangka Pemikiran}

Merek yang ada di sosial media adalah disukai oleh konsumen karena menyediakan konten yang cukup untuk mereka yang menggunakannya sebagai saluran layanan dan informasi sumber (Leggatt, 2010). Sosial media meningkatkan kemampuan pemrosesan informasi, meningkatkan kepercayaan dalam proses keputusan pembelian, meningkatkan kepuasan karena jasa nama merek (Bulearca \& Bulearca, 2010). Booth dan Matic (2011) menyatakan kecepatan itu dan tingkat interaksi adalah yang paling dalam manfaat Social Media.

Di antara yang lainnya, kekuatan Social Media Marketing meliputi: kemampuan untuk menjangkau segmen yang belum dimanfaatkan (Keller, 2009); menyebarkan informasi (Ulusu, 2010; Kim \& Ko, 2010); secara efektif dalam hal waktu, biaya dan jangkauan (Kaplan \& Haenlein, 2010); meningkatkan reputasi, keandalan, dan kredibilitas merek (Fournier \& Avery, 2011); serta positif asosiasi dan loyalitas (Muñiz \& Schau, 2005).

Hartzel et al. (2011) telah mencatat bahwa strategi pemasaran interaktif yang menggunakan tautan sosial media seperti Facebook dan Twitter akan secara positif mempengaruhi brand image dan menciptakan efek leverage antara merek dan konsumen. Efek viral di antara pengguna sosial media memungkinkan merek untuk didiskusikan dan telah dikenal luas di antara sejumlah besar pengguna (Kumar et al., 2011; Sharma \& Verma, 2018).

Tsimonis dan Dimitriadis (2014) telah mengungkapkan bahwa kesadaran merek merupakan salah satu output utama yang diharapkan dari kegiatan Social Media Marketing suatu bisnis. Temuan yang ditunjukkan oleh Fanion (2011) telah menunjukkan bahwa Social Media adalah alat yang signifikan dalam membentuk dan meningkatkan kesadaran merek. Seo dan Park (2018) telah menemukan bahwa kegiatan Social Media Marketing dalam industri penerbangan secara positif mempengaruhi kesadaran merek dan brand image. Kim dan Ko (2010) menemukan bahwa Social Media Marketing secara positif mempengaruhi perilaku pembelian kembali pelanggan. Tatar dan Erdogmus (2016) menyatakan bahwa kegiatan Social Media Marketing dapat mempengaruhi kesadaran merek, niat beli, dan loyalitas merek pelanggan.

Berdasarkan uraian variabel-variabel tersebut, kerangka pemikiran dalam penelitian ini dapat digambarkan seperti Gambar 1.

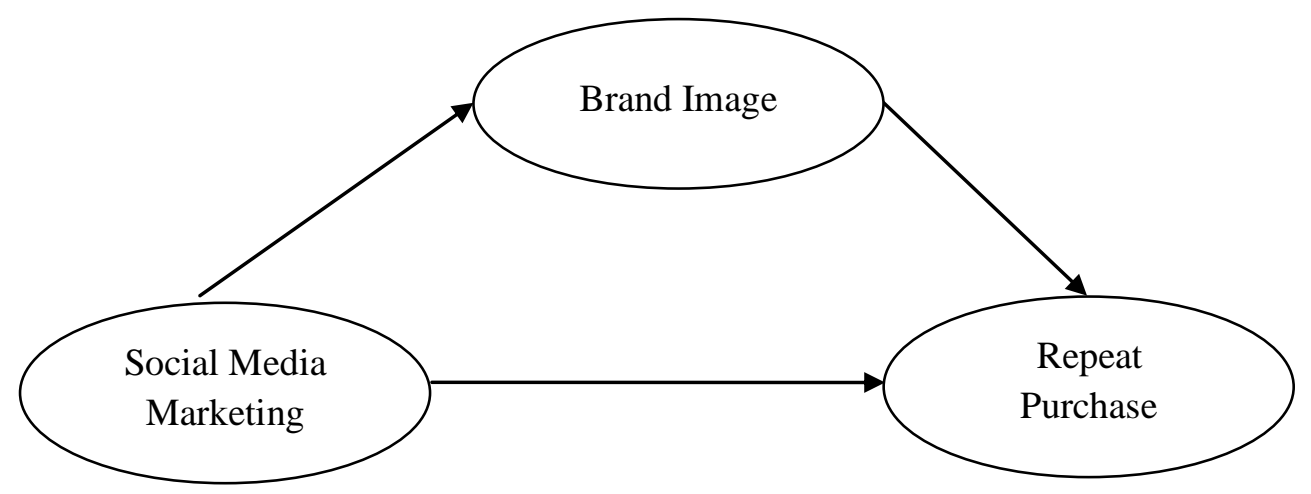

\section{Gambar 1. Kerangka Pemikiran}

Sumber: Diolah penulis, 2019. 
Berdasarkan uraian hubungan antar variabel tersebut seperti ditunjukkan Gambar 1 bisa memunculkan beberapa hipotesis. Rumusan hipotesis yang diajukan dalam penelitian ini berdasarkan kerangka pemikiran tersebut adalah:

H1 : Social media marketing berpengaruh secara signifikan terhadap brand image.

H2 : Social media marketing berpengaruh secara signifikan terhadap repeat purchase.

H3: Brand image berpengaruh secara signifikan terhadap repeat purchase.

H4: Brand image memediasi pengaruh Social media marketing terhadap repeat purchase.

\section{METODE PENELITIAN}

Penelitian ini menggunakan pendekatan asosiatif. Lokasi penelitian ini di kota Medan dengan subjek masyarakat kota Medan yang telah melakukan pembelian di lima restaurant fast-food di kota Medan. Obyek di dalam penelitian ini adalah gerai KFC, McDonald's, A\&W, Hoka-Hoka Bento, dan CFC.

\section{Defnisi Operasional Variabel}

Definisi operasional diperlukan untuk menyamakan asumsi-asumsi terhadap permasalahan yang dibahas. Definisi operasional dari variabel-variabel dalam penelitian ini diuraikan sebagai berikut.

\section{Variabel Terikat $(Y)$}

Variabel terikat dalam penelitian ini adalah repeat purchase. Repeat purchase merupakan keinginan konsumen untuk melakukan pembelian kembali di waktu yang akan datang. Pengukuran yang digunakan di dalam variabel ini adalah:
a. Fast-Food Restaurant merupakan pilihan utama konsumen dalam tindakan membeli makanan.
b. Konsumen mempunyai keinginan untuk membeli kembali.

Variabel Mediator (Z)

Variabel mediator dalam penelitian ini adalah brand image. Dalam penelitian ini, brand image adalah persepsi yang terdapat di dalam benak konsumen mengenai restaurant fast-food yang terdapat di kota Medan. Pengukuran yang digunakan di dalam variabel ini adalah:

1. Atribut adalah fitur yang konsumen pikirkan mengenai produk atau jasa yang ditawarkan melalui sosial media, dimana:

a. Informasi produk yang ditampilkan di sosial media fast-food restaurant bersifat jelas.

b. Informasi yang diberikan di dalam sosial media mengenai munculnya produk baru juga ditampilkan di dalam sosial media.

2. Benefit adalah keuntungan yang konsumen pikirkan mengenai sebuah produk dan jasa yang diterima oleh konsumen, dimana:

a. Dengan menggunakan sosial media, maka konsumen akan dapat menerima informasi dengan lebih cepat.

b. Dengan menggunakan sosial media, konsumen dapat lebih mudah dalam mendapatkan informasi.

3. Attitude adalah evaluasi yang dilakukan oleh konsumen mengenai sebuah brand, dimana:

a. Kepercayaan terhadap brand fast-food restaurant tersebut bertambah ketika menggunakan sosial media.

b. Konsumen tertarik dengan fast-food restaurant karena menggunakan sosial media.

Variabel Bebas (X)

Variabel bebas dalam penelitian ini adalah social media marketing. Social Media Marketing dalam penelitian ini didefinisikan sebagai sebuah tools atau alat yang dapat menghubungkan antara merek dengan konsumennya dan menawarkan hubungan dan interaksi sosial. Variabel social media marketing mempunyai beberapa indikator 
atau dimensi yang dapat digunakan dalam mengukur, yaitu:

1. Be Active (menjadi lebih aktif) adalah sosial media perlu aktif dalam melakukan posting, dimana:

a. Sosial media fast-food restaurant aktif dalam posting melalui sosial media dalam menampilkan informasi.

b. Sosial media fast-food restaurant aktif melakukan postingan di sosial media berupa forum diskusi dengan konsumen.

2. Be Interesting (menjadi lebih menarik) adalah sosial media memberikan konten yang menarik konsumennya, dimana:

a. Sosial media fast-food restaurant sering menampilkan topik yang terbaru.

b. Sosial media fast-food restaurant memberikan topik yang interaktif terhadap konsumennya.

3. Be Humble (menjadi lebih rendah hati) adalah tidak memancarkan sifat yang superioritas kepada konsumennya, dimana:

a. Ketika menjawab pertanyaan dari konsumen, tidak bersifat arogan atau terlihat memaksa.

b. Bersedia memberikan jawaban kepada konsumen dengan telaten.

4. Be unprofessional (menjadi lebih tidak profesional) adalah sosial media perlu terlihat tidak terlalu bersikap sangat profesional di depan konsumen, namun dapat bersikap merangkul konsumennya, dimana:

a. Sosial media fast-food restaurant mau terbuka terhadap kritik dan saran dari konsumennya.

b. Sosial media fast-food restaurant menjawab pertanyaan konsumen dengan ramah.

5. Be honest (menjadi lebih jujur) adalah konten yang disediakan oleh sosial media harus memberikan jawaban yang jujur dan dapat dipertanggungjawabkan, dimana: a. Sosial media fast-food restaurant menyediakan informasi yang dapat dipercaya.

b. Sosial media fast-food restaurant segera mengklarifikasi kesalahan penulisan atau informasi kepada konsumen.

\section{Populasi dan Sampel}

Populasi dalam penelitian ini adalah semua konsumen yang telah melakukan pembelian di lima restaurant fast-food yang terdapat di kota Medan, yaitu gerai KFC, McDonald's, A \&W, Hoka-Hoka Bento, dan CFC.

Menurut Hair et al. (2014), jumlah sampel yang ideal dan representatif adalah jumlah indikator pada variabel dikalikan 5 10. Pada penelitian ini, terdapat 21 indikator. Dengan demikian, batas minimal responden untuk penelitian ini adalah $21 \times 5=105$ orang, sedangkan batas maksimalnya $21 \times 10$ $=210$ orang. Karakteristik sampel yang diambil adalah yang pernah mengonsumsi makanan cepat saji di Kota Medan dalam kurun waktu 6 bulan, aktif di sosial media, serta berusia 18 - 40 tahun. Sampel yang diambil di dalam penelitian ini adalah berjumlah 140 responden.

\section{Sumber dan Teknik Pengumpulan Data}

Dalam penelitian ini, jenis data yang dikumpulkan bersumber dari data primer. Teknik pengumpulan data yang digunakan adalah daftar pertanyaan (questionnaire) dan wawancara (interview).

\section{Teknik Analisis Data}

Penelitian ini menggunakan metode analisis jalur (path analysis) untuk menguji persamaan regresi yang melibatkan beberapa variabel eksogen (bebas) dan endogen (terikat). 


\section{HASIL ANALISIS}

Penelitian ini menggunakan analisis jalur (path analysis). Persamaan model analisis jalur dalam penelitian ini adalah:

$$
\begin{aligned}
& \mathrm{BIM}=0,267 \mathrm{SMM}+\varepsilon_{1} \\
& \mathrm{REP}=0,267 \mathrm{SMM}+0,245 \mathrm{BIM}+\varepsilon_{2}
\end{aligned}
$$

Hasil analisis data untuk penelitian ini ditunjukkan Gambar 2. Nilai-nilai koefisien yang ditunjukkan dalam Gambar 2 memperlihatkan pengaruh langsung dan tidak langsung antar-variabel penelitian. Uraian masing-masing pengaruh itu sebagai berikut.

Pertama, jalur pengaruh langsung (direct effect) dari social media marketing (SMM) terhadap repeat purchase (REP) memiliki nilai koefisien jalur $\left(p_{2}\right)$ sebesar 0,225 atau positif, serta nilai probabilitas (Sig.) sebesar 0,018 atau bersifat signifikan. Nilai yang positif dan signifikan tersebut bermakna jika tingkat social media marketing tinggi maka repeat purchase juga tinggi; sebaliknya, jika social media marketing rendah maka repeat purchase juga rendah.

Kedua, jalur pengaruh langsung (direct effect) dari social media marketing (SMM) terhadap brand image (BIM) memiliki nilai koefisien jalur $\left(p_{1}\right)$ sebesar 0,267 atau positif, dan nilai probabilitas (Sig.) sebesar 0,006 atau bersifat signifikan. Nilai yang positif dan signifikan tersebut bermakna jika tingkat social media marketing tinggi maka brand image juga tinggi; sebaliknya, jika tingkat social media marketing rendah maka brand image juga rendah.

Ketiga, jalur pengaruh langsung (direct effect) dari brand image (BIM) terhadap repeat purchase (REP) diperoleh memiliki nilai koefisien jalur $\left(p_{3}\right)$ sebesar 0,245 atau positif, dan nilai probabilitas (Sig.) sebesar 0,010 atau bersifat signifikan. Nilai yang positif dan signifikan tersebut bermakna jika brand image tinggi maka repeat purchase juga tinggi; sebaliknya, jika brand image rendah maka repeat purchase juga rendah.

Keempat, jalur pengaruh tidak langsung (indirect effect) dari social media marketing (SMM) terhadap repeat purchase (REP) melalui brand image (BIM) adalah sebesar $p_{1}$ $(0,267) \times p_{3}(0,245)=0,065$. Sementara itu, pengaruh langsung (direct effect) dari social media marketing (SMM) terhadap repeat purchase (REP) sebesar $p_{2}=0,225$. Dengan demikian, nilai koefisien pengaruh tidak langsung $(0,065)<$ nilai koefisien pengaruh langsung (0,225). Perbandingan itu bermakna bahwa brand image (BIM) terbukti memiliki peran sebagai mediator.

\section{Pembahasan}

Pada bagian ini dilakukan pembahasan atas hasil-hasil penelitian dikaitkan dengan hasil-hasil penelitian terdahulu.

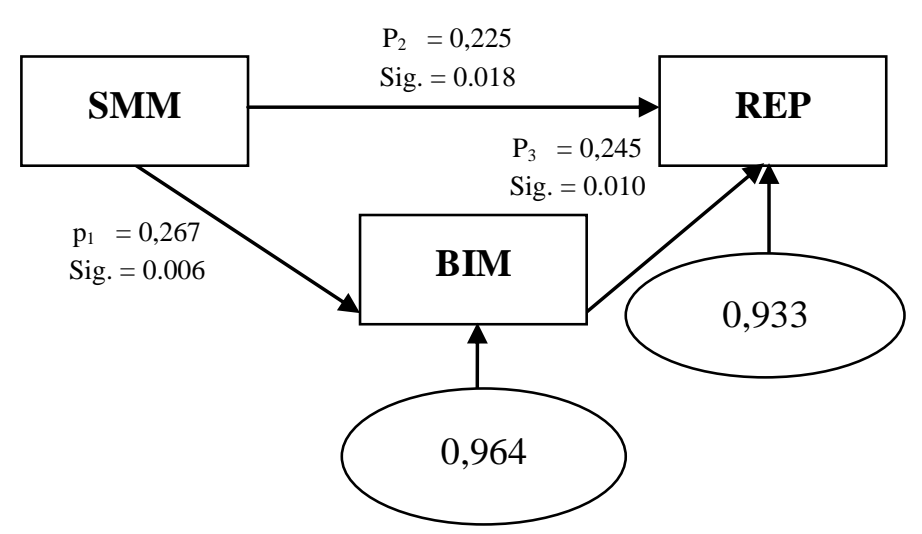

\section{Gambar 2. Model Analisis Jalur (Path Analysis)}

Sumber: Data primer diolah, 2019. 


\section{Pengaruh Social Media Marketing terhadap Brand Image}

Social media marketing diperoleh terbukti berpengaruh terhadap brand image. Hasil ini dapat dijelaskan bahwa pemasaran melalui sosial media dengan memberikan pelayanan dengan menjawab pertanyaan dari konsumen dengan sabar dan menggunakan bahasa yang sopan maka dapat meningkatkan brand image dari fast-food restaurant atau restoran cepat saji.

Hal tersebut juga diketahui berdasarkan distribusi jawaban responden tentang social media marketing yang berkaitan dengan pelayanan yang baik serta mampu menjawab pertanyaan dari konsumen mampu mempengaruhi brand image atau yang dapat disebut sebagai brand image atau evaluasi konsumen terhadap brand tersebut. Dengan demikian, adanya pelayanan yang baik melalui social media marketing maka dapat mempengaruhi brand image di dalam atributnya.

Hasil penelitian Anizir dan Wahyuni (2017) menunjukkan bahwa social media marketing berpengatuh positif dan signifikan terhadap brand image. Begitu juga hasil penelitian As'ad dan Alhadid (2014) yang menunjukkan adanya hubungan signifikan dari penggunaan social media marketing terhadap brand equity.

Selanjutnya, penelitian Kristiani dan Dharmayanti (2017) menunjukkan bahwa social media marketing memiliki pengaruh terhadap brand image. Beberapa penelitian lain juga menyimpulkan bahwa social media marketing memiliki pengaruh terhadap brand image (Bilgin, 2018; Wijaya \& Putri, 2013; Perera \& Perera, 2016).

\section{Pengaruh Brand Image terhadap Repeat Purchase}

Brand image teridentifikasi berpengaruh terhadap repeat purchase. Hasil ini dapat dijelaskan bahwa dengan adanya brand image dapat meningkatkan repeat purchase dari konsumennya melalui pemberian atribut, yaitu tidak hanya memberikan memberikan informasi yang jelas tetapi juga memberikan informasi produk yang up-to-date.

Dengan adanya atribut yang baik dari brand image itu sendiri maka dapat mempengaruhi pembelian berulang atau repeat purchase dari konsumennya. Schultz (2005) menyatakan bahwa pelanggan yang loyal terhadap merek tertentu akan merekomendasikannya kepada orang lain dan tidak mudah dipengaruhi pesaing untuk melakukan pembelian (Sondoh et al., 2007). Hasil penelitian Pamungkas dan Widodo (2018) juga menunjukkan brand image berpengaruh terhadap keputusan pembelian ulang yang dimediasi oleh kepuasan konsumen.

Hasil-hasil penelitian milik Damayanti dan Wahyono (2015) serta Kristiani dan Dharmayanti (2017) juga menunjukkan bahwa terdapat pengaruh brand image terhadap repeat purchase. Beberapa penelitian lain menyimpulkan bahwa brand image berpengaruh terhadap repeat puchase (Efendi et al., 2017; Yunaida, 2017; Farizan et al., 2019; Puspitasari \& Nailis, 2018; Subaebasni et al., 2019; Desi et al., 2017; Ramadhan \& Santosa, 2017; Semuel \& Wibisono, 2019; Poturak \& Softic, 2019; Zhang, 2015; Wijaya \& Astuti, 2018; Lin \& Lin, 2007; Ranjbarian et al., 2012; Fahmi, 2018).

\section{Pengaruh Social Media Marketing terhadap Repeat Purchase}

Social media marketing diperoleh terbukti berpengaruh signifikan terhadap repeat purchase. Dengan demikian dapat dijelaskan bahwa pemasaran melalui sosial media dengan memberikan pelayanan yang baik dan memberikan pelayanan dengan bahasa yang sopan dan menjawab pertanyaan dari konsumen adalah memiliki pengaruh 
yang lemah kepada repeat purchase atau pembelian berulang dari konsumennya. Hal itu dapat dikarenakan pemasaran dari sosial media itu sendiri tidak berarti terhadap pembelian berulang dari konsumen.

Hal tersebut dapat dilihat bahwa variabel "be humble" yang memberikan pengaruh yang tidak signifikan terhadap pembelian berulang atau repeat purchase. Hanya berupa memberikan pelayanan yang baik dan sabar melalui sosial media memiliki pengaruh bisa disebut tidak signifikan di dalam pembelian berulang, yaitu berupa memilih fast-food restaurant menjadi pilihan utama dari konsumen dan mau untuk melakukan pembelian kembali di fast-food restaurant tersebut.

Hasil penelitian milik Kristiani dan Dharmayanti (2017) menunjukkan bahwa social media marketing berpengaruh terhadap repeat purchase. Hasil penelitian milik Kuspriyono dan Nurelasari (2018) juga menunjukkan bahwa social media marketing memiliki pengaruh positif dan signifikan atas purchase intention. Beberapa penelitian lain ikut menyimpulkan bahwa social media marketing memiliki pengaruh terhadap repeat puchase (Kodippili et al., 2016; Muchardie et al., 2016; Imron et al., 2018).

\section{SIMPULAN}

Berdasarkan hasil penelitian diketahui bahwa bahwa terbukti social media marketing berpengaruh signifikan terhadap brand image; brand image berpengaruh signifikan terhadap repeat purchase; dan, social media marketing berpengaruh signifikan terhadap repeat purchase. Secara tidak langsung, hasil penelitian membuktikan bahwa social media marketing tidak berpengaruh terhadap repeat purchase melalui brand image.

Rekomendasi yang diberikan berdasarkan kesimpulan tersebut adalah perlu memberikan pelayanan yang baik kepada konsumen. Pelayanan yang baik kepada konsumen adalah berupa kecepatan dan sabar dalam melayani konsumen. Karenanya, fastfood restaurant perlu mempertimbangkan dengan membuat FAQ (Frequently Asked Question) yang memudahkan konsumen untuk memahami setiap informasi yang diberikan oleh fast-food restaurant.

Rekomendasi kedua adalah melaksanakan training kepada pegawai fast-food restaurant tersebut dalam penanganan menjawab pertanyaan dari konsumennya. Training tersebut dapat dilakukan untuk meningkatkan pelayanan fast-food restaurant melalui sosial media seperti facebook dan twitter. Dengan memberikan training kepada pegawai tersebut dan memberikan serta menekankan pada SOP (Standar Operasional Perusahaan) maka diharapkan pelayanan sosial media di fast-food restaurant menjadi lebih baik dan terstandar.

Rekomendasi ketiga adalah untuk penelitian selanjutnya dapat mempertimbangkan beberapa variabel bebas yang belum dipakai di dalam penelitian ini untuk mengetahui faktor-faktor lain yang dapat mempengaruhi repeat purchase. Variabel bebas yang lain adalah dapat berupa brand trust atau customer intention. Selain itu, penelitian selanjutnya juga dapat menggunakan objek yang lainnya selain fast-food restaurant, misalnya adalah dapat berupa restaurant Japanese, restaurant Western atau restaurant Chinese. Penelitian ini juga dapat menggunakan objek lainnya selain restaurant misalnya pada cafe atau fashion product.

\section{REFERENSI}

Aaker, D.A. 2008. Managing Brand Equity: Capitalizing on the Value of a Brand Name. New York: Free Press.

Aisha, N. \& Kurnia, E. 2018. Pengaruh Kuantitas Pelayanan dan Kualitas Pelayanan terhadap Citra Merek pada Universitas Muhammadiyah Sumatera 
Utara. Jurnal Samudra Ekonomi dan Bisnis. 9(2): 128-137.

Anizir, A. \& Wahyuni, R. 2017. Pengaruh Social Media Marketing terhadap Brand Image Perguruan Tinggi Swasta di Kota Serang. Jurnal Sains Manajemen. 3(2): 1-14.

As'ad, H.A.-R. \& Alhadid, A.Y. 2014. The Impact of Social Media Marketing on Brand Equity: An Empirical Study on Mobile Service Providers in Jordan. Review of Integrative Business \& Economics Research. 3(1): 315-324.

Berthon, P.R., Pitt, L.F. \& Kates, S.M. 2007.

When Customers Get Clever: Managerial Approaches to Dealing with Creative Consumers. Business Horizons. 50: 39-47.

Bilgin, Y. 2018. The Effect of Social Media Marketing Activities on Brand Awareness, Brand Image and Brand Loyalty. Business \& Management Studies: An International Journal. 6(1): 128-148.

Booth, N. \& Matic, J.A. 2011. Mapping and Leveraging Influencers in Social Media to Shape Corporate Brand Perception. Corporate Communications: An International Journal. 16(3): 184-191.

Bruhn, M., Schoenmueller, V. \& Schäfer, D.B. 2012. Are Social Media Replacing Traditional Media in Terms of Brand Equity Creation? Management Research Review. 35(9): 770-790.

Bulearca, M. \& Bulearca, S. 2010. Twitter: A Viable Marketing Tool for SMEs. Global Business and Management Research: An International Journal. 2(4): 296-309.

Chairunnisa \& Priyono, A. 2018. Interaksi antara Perceived Value, Transaction Cost, dan Repurchase Intention dalam Transaksi On-Line. Matrik: Jurnal Manajemen, Strategi Bisnis dan Kewirausahaan. 12(1): 49-60.

Chen, Y., Fay, S. \& Wang, Q. 2011. The Role of Marketing in Social Media: How Online Consumer Reviews Evolve. Journal of Interactive Marketing. 25(2): 85-94.
Chiu, C., Wang, E.T.G., Fang, Y. \& Huang, H. 2014. Understanding Customers' Repeat Purchase Intentions in B2C ECommerce: The Roles of Utilitarian Value, Hedonic Value and Perceived Risk. Information Systems Journal. 24(1): 85-114.

Chou, S.-W. \& Hsu, C.-S. 2015. Understanding Online Repurchase Intention: Social Exchange Theory and Shopping Habit. Information Systems and E-Business Management. 14(1): $19-45$.

Coon, M. 2010. Social Media Marketing: Successful Case Studies of Businesses Using Facebook and YouTube with an In-Depth Look into the Business Use of Twitter. Thesis. Stanford, CA: Stanford University.

Damayanti, C. \& Wahyono, W. 2015. Pengaruh Kualitas Produk, Brand Image terhadap Loyalitas dengan Kepuasan sebagai Variabel Intervening. Management Analysis Journal. 4(3): 236-251.

Desi, D., Bahri, S. \& Ponirin. 2017. Pengaruh Citra Merek dan Pengetahuan Produk terhadap Keputusan Pembelian Ulang Air Mineral Cleo di Alfamidi Kota Palu. Jurnal Ilmu Manajemen Universitas Tadulako. 3(2): 145-150.

Drury, G. 2008. Opinion Piece: Social Media should Marketers Engage and How can It be Done Effectively? Journal of Direct Data Digit Marketing and Practice. 9(3): 274-277.

Efendi, Z., Widyaningrum, M.E. \& Imamah, N. 2017. Pengaruh Promosi, Citra Merek, dan Kepuasan Konsumen terhadap Pembelian Berulang Produk Elzatta di Surabaya. Jurnal Manajemen Branchmark. 3(3): 1097-1109.

Fahmi, M. 2018. The Influence of Quality of Service, Relational Marketing and Corporate Image against the Loyalty of Suppliers in PT. Raja Putra Manggala. Proceedings. International Conference of ASEAN Prespective and Policy (ICAP): 377-385. 
Fanion, R. 2011. Social Media Brings Benefits to top Companies. Central Penn Business Journal. 27(3): 76-77.

Farizan, N., Rohman, F. \& Hussein, A.S. 2019. The Effect of Brand Identity, Brand Image, and Perceived Value on Loyalty with Customer Satisfaction as Mediation Variable for Costumer Fresh Juice Bintaro. Journal of Applied Management (JAM). 17(1): 127-132.

Fournier, S. \& Avery, J. 2011. The Uninvited Brand. Business Horizons. 54(3): 193207.

Gordhamer, S. 2009. 4 Ways Social Media is Changing Business. Retrieved October 23, 2019, from https://mashable.com/ 2009/09/22/social-media-business/

Gunelius, S. 2011. 30 Minute Social Media Marketing. United States of America: McGraw \& Hill Companies Inc.

Gupta, S. \& Kim, H.W. 2007. Developing the Commitment to Virtual Community: The Balanced Effects of Cognition and Affect. Information Resources Management Journal. 20(1): 28-45.

Hair, J.F., Black, W.C., Babin, B.J. \& Anderson, R.E. 2014. Multivariate Data Analysis. $7^{\text {th }}$ ed. New Jersey: Pearson Education Limited.

Hartzel, K.S., Mahanes, C.J., Maurer, G.J., Sheldon, J., Trunick, C. \& Wilson, S.J. 2011. Corporate Posts and Tweets: Brand Control in Web 2.0. Journal of Information \& Knowledge Management. 10(1): 51-58.

Heidemann, J., Klier, M. \& Probst, F. 2012. Online Social Networks: A Survey of a Global Phenomenon. Computer Networks. 56(18): 3866-3878.

Imron, A.S., Wardani, N.H. \& Rokhmawati, R.I. 2018. Analisis Pengaruh Pemasaran Media Sosial terhadap Loyalitas Konsumen: Studi pada Transportasi Online (Go-Jek Indonesia). Jurnal Pengembangan Teknologi Informasi dan Ilmu Komputer. 2(9): 2570-2578.

Iversen, N.M. \& Hem, L.E. 2008. Provenance Association as Core Value of Place Umbrella Brands: A Framework of Characteristics. European Journal of
Marketing. 42(5/6): 603-626.

Jokinen, T. 2016. Branding in Social Media and the Impact of Social Media on Brand Image. School of Business and Culture International Business.

Kaplan, A.M. \& Haenlein, M. 2010. Users of the World, Unite! The Challenges and Opportunities of Social Media. Business Horizons. 53(1): 59-68.

Keller, K.L. 2009. Building Strong Brands in a Modern Marketing Communications Environment. Journal of Marketing Communications. 15(2/3): 139-155.

Kim, A.J. \& Ko, E. 2010. Impacts of Luxury Fashion Brand's Social Media Marketing on Customer Relationship and Purchase Intention. Journal of Global Fashion Marketing. 1(3): 164171.

Kodippili, G., Jayawickrama, M.T., Yugandari, O.W.D., Pamudini, S.D. \& Samarasinghe, H.M.U.S.R. 2016. The Influence of Social Media Marketing on Customer Loyalty towards Clothing Stores. Proceedings. NCTM-2016: 5968.

Kotler, P. 2005. Manajemen Pemasaran. Edisi Kesebelas. Jakarta: PT. Indeks.

Kotler, P. \& Keller, K.L. 2009. Manajemen Pemasaran. Edisi Ketigabelas. Jakarta: PT. Erlangga.

Kristiani, P. \& Dharmayanti, D. 2017. Pengaruh Social Media Marketing terhadap Repeat Purchase dengan Variabel Intervening Perceived Service Quality dan Brand Image pada Industri Fast-Food Restaurant di Surabaya. Petra Business \& Management Review. 3(1): 67-84.

Kumar, V., Batista, L. \& Maull, R. 2011. The Impact of Operations Performance on Customer Loyalty. Service Science, 3(2): 158-171.

Kuo, Y.-F., Hu, T.-L. \& Yang, S.-C. 2013. Effects of Inertia and Satisfaction in Female Online Shoppers on RepeatPurchase Intention: The Moderating Roles of Word-of-Mouth and Alternative Attraction. Journal of Service Theory and Practice. 23(3): 168-187. 
Kuspriyono, T. \& Nurelasari, E. 2018. Pengaruh Social Media Marketing terhadap Customer Bonding dan Purchase to Intention. Cakrawala Jurnal Humaniora. 18(2): 235-242.

Lee, H., Lee, C. \& Wu, C. 2011. Brand Image Strategy Affects Brand Equity After M\&A. European Journal of Marketing. 45(7/8): 1091-1111.

Leggatt, H. 2010. Rebuild Brand Loyalty with Social Media. Retrieved October 23, 2019. http://www.bizreport.com/2010/ 08/price-sensitive-shoppers-stillseeking-out-deals.html

Li, C. \& Bernoff, J. 2011. Groundswell: Winning in a World Transformed by Social Technologies. Boston, MA: Harvard Business Review Press.

Lin, J. C. \& Liang, H. 2011. The Influence of Service Environments on Customer Emotion and Service Outcomes. Managing Service Quality: An International Journal. 21(4): 350-372.

Lin, N.-H. \& Lin, B.-S. 2007. The Effect of Brand Image and Product Knowledge on Purchase Intention Moderated by Price Discount. Journal of International Management Studies: 121-132.

Lipsman, A., Mudd, G., Rich, M. \& Bruich, S. 2012. The Power of "Like": How Brands Reach (and Influence) Fans through Social-Media Marketing. Business Horizons. 52(4): 357-365.

Mangold, W.G. \& Faulds, D.J. 2009. Social Media: The New Hybrid Element of the Promotion Mix. Business Horizons. 52(4): 357-365.

Mayfield, A. 2008. What is Social Media. London: iCrossing.

Mihalcea, A. \& Savulescu, R. 2013. Social Networking Sites: Guidelines for Creating New Business Opportunities through Facebook, Twitter and LinkedIn. Management Dynamics in the Knowledge Economy. 1: 39-54.

Muchardie, B.G., Gunawan, N.H. \& Annetta, Y. 2016. Effect of Social Media Marketing on Customer Engagement and its Impact on Brand Loyalty in
Caring Colours Cosmetics, Martha Tilaar. Binus Business Review. 7(1): 83-87.

Muñiz, A.M. \& Schau, H.J. 2005. Religiosity in the Abandoned Apple Newton Brand Community. Journal of Consumer Research. 31(4): 737-747.

Ndubisi, N.O. \& Moi, C.T. 2005. Customers Behaviourial Responses to Sales Promotion: The Role of Fear of Losing Face. Asia Pacific Journal of Marketing and Logistics. 17(1): 32-49.

Pamungkas, A.D. \& Widodo, A. 2018. Pengaruh Brand Image terhadap Keputusan Pembelian Ulang Green Product Pertamax Turbo (Ron 98) dengan Kepuasan Konsumen sebagai Variabel Intervening. E-Proceeding of Management. 5(2): 2584-2592.

Perera, G.R. \& Perera, I. 2016. Influence of Social Media Marketing on the Brand Image of Organizations in the Hospitality Industry of Sri Lanka. International Journal of Asian Business and Information Management. 7(1): 30-41.

Poturak, M. \& Softic, S. 2019. Influence of Social Media Content on Consumer Purchase Intention: Mediation Effect of Brand Equity. Eurasian Journal of Business and Economics. 12(23): 1743.

Puspitasari, E.D. \& Nailis, W. 2018. Pengaruh Lokasi dan Citra Merek terhadap Keputusan Pembelian Konsumen (Studi Kasus pada Konsumen KFC Dermaga Point Palembang. JEMBATAN - Jurnal Ilmiah Manajemen Bisnis dan Terapan. 15(1): 23-32.

Ramadhan, A.G. \& Santosa, S.B. 2017. Analisis Pengaruh Kualitas Produk, Kualitas Pelayanan, dan Citra Merek terhadap Minat Beli Ulang pada Sepatu Nike Running di Semarang melalui Kepuasan Pelanggan sebagai Variabel Intervening. Diponegoro Journal of Management. 6(1): 1-12.

Ranjbarian, B., Sanayei, A., Kaboli, M.R. \& Hadadian, A. 2012. An Analysis of Brand Image, Perceived Quality, 
Customer Satisfaction and Repurchase Intention in Iranian Department Stores. International Journal of Business and Management. 7(6): 40-48.

Riezebos, R.K. 2003. Brand ManagementA theoretical and Practical Approach. Harlow, United Kingdom: Pearson Education Limited.

Schiffman, L. \& Kanuk, L. 2010. Consumer Behavior. New Jersey: Pearson Prentice Hall.

Schultz, D.E. 2005. The Loyalty Paradox. Marketing Management. 14(5): 1011.

Semuel, H. \& Wibisono, J. 2019. Brand Image, Customer Satisfaction dan Customer Loyalty Jaringan Supermarket Superindo di Surabaya. Jurnal Manajemen Pemasaran. 13(1): 27-34.

Seo, E.-J. \& Park, J.-W. 2018. A Study on the Effects of Social Media Marketing Activities on Brand Equity and customer Response in the Airline Industry. Journal of Air Transport Management. 66: 36-41.

Sharma, S. \& Verma, H.V. 2018. Social Media Marketing: Evolution and Change. Social Media Marketing. In: Heggde G., Shainesh G. (eds): 19-36. Singapore: Palgrave Macmillan.

Shojaee, S. \& Azman, A.B. 2013. An Evaluation of Factors Affecting Brand Awareness in the Context of Social Media in Malaysia. Asian Social Science. 9(17): 72-78.

Sigala, M. \& Marinidis, D. 2009. Exploring the Transformation of Tourism Firms' Operations and Business Models through the Use of Web Map Services. Proceedings. European and Mediterranean Conference on Information Systems: 1-13. Retrieved from http:// citeseerx.ist.psu.edu/viewdoc/download ?doi=10.1.1.527.5404\&rep=rep1\&type $=$ pdf

Simamora, B. 2000. Manajemen Pemasaran Internasional. Jakarta: Salemba Empat. Solis, B. 2011. Engage: The Complete Guide for Brands and Businesses to Build, Cultivate, and Measure Succes in the New Web. New Jersey: John Wiley \& Sons.

Sondoh, S.L., Omar, M.W., Wahid, N.A., Ismail, I. \& Harun, A. 2007. The Effect of Brand Image on Overall Satisfaction and Loyalty Intention in the Context of Color Cosmetic. Asian Academy of Management Journal. 12(1): 83-107.

Strauss, J. \& Frost, R. 2009. E-Marketing. Upper Saddle River, NJ.: Prentice Hall. Inc.

Subaebasni, S., Risnawaty, H. \& Wicaksono, A.R.A. 2019. Effect of Brand Image, the Quality and Price on Customer Satisfaction and Implications for Customer Loyalty PT Strait Liner Express in Jakarta. International Review of Management and Marketing. 9(1): 90-97.

Tatar, S.B. \& Erdogmus, I.E. 2016. The Effect of Social Media Marketing on Brand Trust and Brand Loyalty for Hotels. Information Technology \& Tourism. 16(3): 249-263.

Tsimonis, G. \& Dimitriadis, S. 2014. Brand Strategies in Social Media. Marketing Intelligence \& Planning. 32(3): 328344.

Tuten, T.L. 2008. Advertising 2.0: Social Media Marketing in a Web 2.0 World. Westport, Connecticut: Greenwood Publishing Group.

Ulusu, Y. 2010. Determinant Factors of Time Spent on Facebook: Brand Community Engagement and Usage Types. Journal of Yasar University. 18(5): 2949-2957.

Weber, L. 2007. Marketing to the Social Web: How Digital Customer Communities Build Your Business. New Jersey: Wiley.

Wijaya, B.S. \& Putri, D.M. 2013. Is Social Media Impactful for University's Brand Image? Jurnal Manajemen Teknologi. 12(3): 278-297.

Wijaya, H.R. \& Astuti, S.R.T. 2018. The Effect of Trust and Brand Image to Repurchase Intention in Online Shopping. Proceedings. International Conference on Economics, Business and Economic Education 2018: 915-928. 
Yang, Y.-F., Wang, G.-L., Song, W.-B., Chen, C.-Y. \& Hung, F.-C. 2011. A Study on Professional Competencies, Brand Image, and Brand Recognition of Taiwan's Mobile Phone Industry. The Journal of Human Resource and Adult Learning. 7(2): 51-65.

Yunaida, E. 2017. Pengaruh Brand Image (Citra Merek) terhadap Loyalitas Konsumen Produk Oli Pelumas Evalube di Kota Langsa. Jurnal Manajemen dan Keuangan. 6(2): 798-807.
Zhang, Y. 2015. The Impact of Brand Image on Consumer Behavior: A Literature Review. Open Journal of Business and Management. 3: 58-62.

Zimmerman, J. \& Sahlin, D. 2011. Social Media Marketing All-in-One for Dummies. Indianapolis, Indiana: John Wiley \& Sons. 